\title{
ANALISIS PEMIKIRAN IBNU KHALDUN TENTANG MEKANISME PASAR DAN PENETAPAN HARGA DALAM PEREKONOMIAN ISLAM
}

\author{
Hendra Pertaminawati \\ Sekolah Tinggi Agama Islam Indonesia \\ Jl. I Gusti Ngurahrai, RT.1/RW.16, Klender, Duren Sawit, Jakarta 13470 \\ Email: hendrawati289@gmail.com
}

\begin{abstract}
The Analysis of Ibnu Khaldun's Concept of Market Mechanism and Price Fixing in Islamic Economics. The market mechanism or price fixing is a trend of free market to make the market price balanced, so it up to the same amount of supply and demand. At this point because there is no excess demand or excess supply, there is no pressure on the price for change again. Supply and demand are not always in equilibrium and some markets may not reach equilibrium quickly when conditions suddenly change, but tendency remains, that the market usually leads to balance. One of the many Muslim scholars to discuss the economic problem of society is Waliuddin Abdurrahman Abu Zaid Ibn Khaldun.
\end{abstract}

Keyword: The price mechanism, supply and demand, market

Abstract: Analisis pemikiran Ibnu Khaldun tentang Mekanisme Pasar dan Penetapan Harga dalam Perekonomian Islam. Mekanisme pasar atau penetapan harga adalah suatu tren pasar bebas untuk membuat harga pasar seimbang sesuai dengan persediaan dan pemintaan. Dalam hal ini, dikarenakan tidak ada permintaan lebih atau persediaan lebih, maka tidak ada pula tekanan untuk merubah harga. Persediaan dan permintaan tidak seterusnya seimbang dan beberapa pasar terkadang tidak mencapai keseimbangan dengan cepat ketika terjadi perubahan situasi, tetapi kecenderunagannya masih ada, sehingga biasanya membuat pasar seimbang lagi. Salah satu pakar Muslim dalam bidang masalah ekonomi masyarakat adalah Waliuddin Abdurrahman Abu Zaid Ibn Khaldun.

Kata kunci: Mekanisme Pasar, Penetapan Harga, Persediaan dan Permintaan, Pasar

\section{Pendahuluan}

Salah satu bidang kajian ekonomi Islam yang menarik untuk dibahas adalah mengenai mekanisme harga dan penetapan harga dalam konteks ekonomi Islam ${ }^{1}$. Dalam penentuan harga suatu barang di suatu kota misal-

${ }^{1}$ Ulfa Jamilatul Farida,'Telaah Kritis Pemikiran Ekonomi Islam Terhadap Mekanisme Pasar Dalam Konteks Ekonomi Islam Kekinian' dalam La_Riba-Jurnal Ekonomi Islam, 2012, (Sleman: 
nya, akan tergantung oleh berkembang atau tidaknya populasi dalam daerah tersebut,bilamana populasi meningkat maka dengan sendirinya pengadaan akan barang-barang kebutuhan pokok mendapat prioritas, sehingga penawaran meningkat dan berakibat pada penurunan harga barang tersebut. Sedangkan untuk barang mewah, permintaannya akan meningkat, sejalan dengan perkembangan kota dan berubahnya gaya hidup. Akibatnya harga barang mewah tersebut pun menjadi naik, sejalan dengan meningkatnya gaya hidup yang mengakibatkan peningkatan permintaan barang mewah ini ${ }^{2}$.

Pengaruh naik turunnya penawaran terhadap harga tergantung pada ketersediaan barang, karena ketika barang-barang yang tersedia sedikit, maka harga-harga akan naik. Namun, bila jarak antara kota dekat dan aman, maka akan banyak barang yang diimpor sehingga ketersediaan barang akan melimpah dan harga-harga akan turun ${ }^{3}$.

Dalam konsep ekonomi Islam penentuan harga juga dilakukan oleh kekuatan-kekuatan pasar, yaitu kekuatan permintaan dan penawaran. Dalam konsep Islam, pertemuan antara permintaan dan penawaran tersebut haruslah terjadi rela sama rela, tidak ada pihak yang merasa terpaksa untuk melakukan transaksi pada tingkat harga tersebut.

Keadaan rela sama rela merupakan kebalikan dari keadaan aniaya, yaitu keadaan di mana salah satu pihak senang di atas kesedihan orang lain. Dalam hal harga, para ahli fiqih merumuskan sebagai the price of the equivalent. Konsep the price of the equivalent ini mempunyai implikasi penting dalam ilmu ekonomi, yaitu keadaan pasar yang kompetitif ${ }^{4}$.

Gambar: 1.1

Keseimbangan Pasar

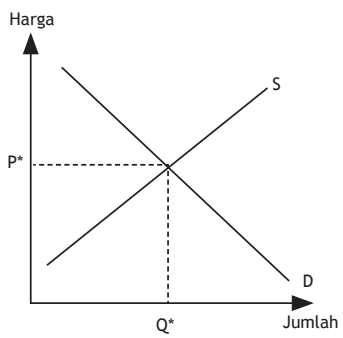

Keseimbangan pasar terjadi pada saaat perpotongan antara kurva supply dan demand dalam keadaan an taraddin minkum (rela sama rela). Bila ada yang mengganggu keseimbangan ini, maka pemerintah harus intervensi pasar.

Sumber: Adiwarman Karim, Ekonomi Mikro Islam, 2008

Universitas Islam Indonesia), hal 257-258

${ }^{2}$ P3EI, Ekonomi Islam, 2014, (Jakarta : Rajawali Pers), 310-311.

${ }^{3}$ P3EI, Ekonomi Islam, hal 311.

${ }^{4}$ Adiwarman Karim, Ekonomi Mikro Islam, 2008 (Jakarta: RajaGrafindo Persada), hal 152. 
Konsep Islam membolehkan monopoly, duopoly, oligopoly dalam artian hanya satu penjual, dua penjual atau beberapa penjual, selama mereka tidak mengambil keuntungan di atas keuntungan normal. Ini merupakan konsekwensi dari konsep the price of the equivalent. Produsen yang beroperasi dengan positif profit akan mengundang produsen lain untuk masuk ke dalam bisnis tersebut, sehingga kurva supply bergeser ke kanan, jumlah output yang ditawarkan bertambah, dan harga akan turun 5 .

Dalam konsep ekonomi Islam, cara pengendalian harga ditentukan oleh penyebabnya. Bila penyebabnya adalah perubahan pada genuine demand dan genuine supply, maka mekanisme pengendalian melalui market intervention. Sedangkan bila penyebabnya adalah distorsi terhadap genuine demand dan genuine supply, maka mekanisme pengendalian dilakukan melalui penghilangan distorsi termasuk penentuan price intervention untuk mengembalikan harga pada keadaan sebelum distorsi ${ }^{6}$.

Kaum muslimin pernah mengalami harga-harga naik di madinah yang disebabkan faktor genuine. Untuk mengatasi hal tersebut Khalifah Umar ibn Khattab melakukan market intervention. Sejumlah besar barang diimpor dari Mesir ke Madinah. Jadi intervensi langsung dilakukan melalui jumlah barang yang ditawarkan. Secara grafis ini digambarkan naiknya barangbarang di madinah digambarkan dengan bergeraknya kurva penawaran ke kiri, sehingga harga naik. Dengan masuknya barang-barang impor dari Mesir, kurva penawaran kembali bergeser ke kanan, yaitu pada tingkat semula. Namun demikian, rendahnya daya beli kaum muslimin pada saat itu, memaksa umar mengeluarkan sejenis cek yang dibagikan kepada mereka yang berhak.

Salah satu cendikiawan muslim yang banyak membahas mengenai masalah ekonomi masyarakat adalah Abdurrahman Abu Zaid Waliuddin Ibnu Khaldun. Ia hidup pada tahun 732 hingga808 H. Beliau yang lahir di Tunis tanggal 27 Mei 1332Mํ. Ia lebih popular dengan sebutan Ibnu Khaldun. Ibnu Khaldun mengkaji problem ekonomimasyarakat dan negara secara empiris, ia menjelaskan fenomena ekonomi secaraaktual, seperti yang ia ungkapkan dalam kitab Muqaddimah-nya dalam bab'harga-harga

${ }^{5}$ Adiwarman Karim, Ekonomi Mikro Islam, hal 153.

${ }^{6}$ Adiwarman Karim, Ekonomi Mikro Islam, hal 154.

${ }^{7}$ Adiwarman Karim, Sejarah Pemikiran Ekonomi Islam, 2010 (Jakarta: RajaGrafindo Persada), hal 391. 
di kota'. Dalam bukunya Muqaddimah itu pula Ibnu Khaldun memberikan bahasan yang luas tentang teori nilai, pembagian kerja dan perdagangan internasional, hukum permintaan dan penawaran, konsumsi,produksi, uang, siklus perdagangan, keuangan publik dan berbagai bahasanmakro ekonomi lainnya yang utamanya berkaitan dengan mekanisme harga dan penetapan harga ${ }^{8}$.

Berpijak pada pentingnya masalah mekanisme harga dan penetapan harga, maka penulis tertarik mengkaji lebih dalam mengenai mekanisme harga dan penetapan harga dalam Pemikiran Ibnu Khaldun.

\section{Sejarah Hidup dan Karya Ibnu Khaldun}

Ibnu khaldun hidup antara abad ke-14 dan 15 M (1332-1406) bertepatan abad ke-8 dan $9 \mathrm{H}$. Mesir pada waktu itu berada di bawah kekuasaan Bani Mamluk. Kota Bagdad jatuh ke tangan bangsa Tartar (654$923 \mathrm{H})$. Dampaknya sangan negatif bagi perkembangan bahasa sastra bagi kebudayaan Arab. Di saat yang bersamaan, berbagai kerajaan muslim di Andalusia mulai runtuh. Satu persatu kota-kota kerajaan Islam jatuh ke tangan kaum Kristen'.

Nasab Ibnu Khaldun digolongkan kepada Muhammad Ibnu Muhammad Ibnu Hasan Ibnu Jabir Ibnu Muhammad Ibnu Ibrahim Abdurrahman Ibnu Khalid. Namun ia dikenal dengan nama Ibnu Khaldun. Nama aslinya adalah Abdurrahman Ibnu Khaldun Al Maghribi Al Hadrami Al Maliki. Digolongkan kepada Al Maghribi, karena dia dilahirkan dan dibesarkan di Maghrib di kotaTunisi, dijuluki Al Hadrami karena keturunannya berasal dari Hadramaut Yaman, dan dikatakan Al Maliki karena ia menganut madzhab Imam Malik. Gelar Abu Zaid diperoleh dari nama anaknya yang tertua Zaid. Panggilan wali Ad Din diperolehnya setelah ia menjadi hakim di Mesir.

Kakek IbnuKhaldun, khalid Ibnu Usman dan keluarganya menetap di kota Carmone selama beberapa waktu sebelum hijrah ke kota Sevilla. Keluarga Khaldun berhasil menjabat beberapa jabatan penting didalam ilmu pengetahuan dan politik di kota ini, antara lain Kuraib Ibnu Khaldun

\footnotetext{
${ }^{8}$ P3EI, Ekonomi Islam, hal 112.

${ }^{9}$ Ibnu Khaldun, Muqaddimah, Terj. Masturi Ilham, dkk, 2014 (Jakarta: Pustaka Al Kautsar), hal 1079
} 
yang terkenal dalam bidang ilmu pengetahuan. Ringkasnya, kedudukan Banu Khaldun di Sevilla sangat terhormat.

Pada awal abad ke-13 M, kerajaan Muwahiddin di Andalus hancur. Sebagian besar kota-kota dan pelabuhannya jatuh ke tangan raja Castilia termasuk kota Sevilla $(1248 \mathrm{M})$. Bani (keluarga) terpaksa hijrah ke Afrika Utara mengikuti jejak Banu Hafs Mengangkat jejak Abu Bakar Muhammad, yaitu kakek kedua Ibnu Khaldun untuk mengatur urusan Negara mereka di Tunisia, dan mengangkat kakek pertama beliau Muhammad Ibnu Abu Bakas untuk mengurus urusan Hijabah (Kantor urusan Keistanaan/Kenegaraan) di Bogie (Bejaya).

Ibnu Khaldun dilahirkan di Tunisia pada Bulan Ramadhan $732 \mathrm{H} /$ $1332 \mathrm{M}$, ditengah-tengah keluarga ilmuan dan terhormat yang berhasil menghimpun antara jabatan ilmiah dan pemerintahan. Dari lingkungan seperti ini Ibnu Khaldun memperoleh dua orientasi yang kuat; pertama, cinta belajar dan ilmu pengetahuan; kedua, cinta jabatan dan pangkat.

Ayahnya bernama Abu Abdullah Muhammad juga berkecimpung dalam bidang politik, kemudian mengundurkan diri dari bidang politik dan menekuni ilmu pengetahuan dan kesufian. Beliau ahli dalam bidang bahasa dan sastra Arab. Meninggal dunia pada tahun 749H/1348 akibat wabah pes yang melanda Afrika Utara dengan meninggalkan lima orang anak termasuk Abdurrahman Ibnu Khaldun yang pada waktu itu berusia 18 tahun.

Ibnu Khaldun mengawali pendidikannya dengan membacadan menghafal Al Qur'an kemudian baru menimba berbagai ilmu dari guru-guru terkenal sesuai dengan bidang masing-masing. Tunisia pada waktu itu merupakan pusat ulama dan sastrawan besar kota-kota di Timur dan Barat, dilanda wabah pes yang dahsat pada tahun $749 \mathrm{H}$, sehingga Ibnu Khaldun Kehilangan kedua orang tuanya dan beberapa orang gurunya, ia tidak dapat melanjutkan studinya dan akhirnya hijrah ke Magrib.

Wafatnya kedua orang tua Ibnu Khaldun saat ia masih remaja merupakan salah satu faktor yang dapat mengurangi keterikatannya terhadap keluarga dan tempat kediamannya serta membuka kesempatan baginya untuk berkelana dan terjun ke dunia politik di berbagai plosok Magrib (Maroko).

Menurut Dr Ali Abdul Wahid Wafi, salah satu yang ahli tentang Ibnu Khaldun, ada dua faktor yang menyebabkan Ibnu Khaldun tidak 
dapat melanjutkan studinya: pertama, wabah pes yang melanda sebagian besar dunia Islam mulai dari Samarkand sampai ke magrib. Kedua, hijrahnya sebagian besar ulama dan sastrawan yang selamat dari wabah pes dari dari Tunisia ke maroko pada tahun 750 M/1349 Hbersama-sama dengan Sulta Abu Al Hasan, penguasa Daulah Bani Marin. Ibnu Khaldun menganggap peristiwa wabah pes ini sebagai wabah besar dalam hidup ini yang menyebabkan ia kehilangan kedua orang tuanya dan sebagian gurugurunya ${ }^{10}$.

Ibnu Khaldun terkenal sebagai ilmuan besar adalah karena karyanya "Muqaddimah". Rasanya memang aneh ia terkenal justru karena muqaddimahnya bukan karena karyanya yang pokok (al Ibar), namun pengantar $A l$ 'Ibarnyalah yang telah membuat namanya diagung-agungkan dalam sejarah intelektualisme. Karya monumentalnya itu telah membuat para sarjana baik di barat atau di Timur begitu mengaguminya. Sampaisampai Windelband dalam filsafat sejarahnya menyebutnya sebagai "tokoh ajaib yang sama sekali lepas, baik dari masa lampau atau masa yang akan datang".

Senarnya Ibnu Khaldun telah memulai kariernya dalam bidang tulis menulis semenjak masa mudanya, tatkala ia sedang menuntut ilmu pengetahuan, kemudian dilanjutkan ketika ia aktif dalam dunia politik dan pemerintahan. Adapun hasil karya-karyanya yang terkenaldi antaranya adalah:

1. Kitab Muqaddimah, yang merupakan buku pertama dari kitab $\mathrm{Al}$ 'Ibar, yang terdiri dari bagian muqaddimah (pengantar). Buku pengantar yang panjang inilah yang merupakan inti dari seluruh persoalan, dan buku tersebut pula lah yang mengangkat nama Ibnu Khaldun menjadi begitu harum. Adapun tema muqaddimah ini adalah gejala-gejala sosial dan sejarahnya.

2. Kitab al 'Ibar, wa Diwan Al Mubtada' wa Al Khabar, fi Ayyam Al 'Arab wa Al Barbar, wa man Asharuhum min dzawi As Sulthan Al 'akbar. (kitab perjalanan dan arsip sejarah zaman permulaan dan zaman Akhir yang mencakup peristiwa politik mengenai orang-orang Arab, NonArab, dan Barbar, serta raja-raja besar yang semasa dengan Mereka), yang kemudian terkenal dengan kitab 'Ibar, yang terdiri dari tiga buku:

${ }^{10}$ Ibnu Khaldun, Muqaddimah, hal 1079-1081 
Buku pertama, adalah sebagian kitab muqaddimah, atau jilid pertama yang berisi tentang: masyarakat dan ciri-cirinya yang hakiki, yaitu pemerintah, kekuasaan, pencaharian, kehidupan, keahlian-keahlian, dan ilmu pengetahua dengan segala sebab dan alasan-alasannya. Buku kedua terdiri dari empat jilid, yaitu jilid kedua, ketiga, keempat dan kelima, yang menguraikan tentang sejarah bangsa Arab, generasigenerasi mereka serta dinasti-dinasti mereka. Di samping itu juga mengandung ulasan tentang bangsa-bansa terkenal dan negara yang sezaman dengan mereka, seperti bangsa Syiria, Persia, Yahudi (Israel), Yunani, Romawi, Turki, dan Franka (orang-orang eropa). Kemudian buku ketiga terdiri dari dua jilid yaitu jilid keenam dan ketujuh, yang berisi tentang sejarah bahasa arbar dan zanata yang merupakan bagian dari mereka, khususnya kerajaan dan negara-negara Magribi (Afrika Utara).

3. Kitab At Tärifbi Ibnu Khaldun wa Rihlatuhu syarqan wa Gharban atau disebut secara ringkas dengan istilah At Ta'rif, dan oleh orang-orang barat disebut dengan otobiografi, merupakan bagian terakhir dari kitab $A l$ 'Ibar yang berisi tentang beberapa bab mengenai kehidupan Ibnu Khaldun. Dia menulis otobiografinya secara sistematis dengan menggunakan metode ilmiah, karena terpisah dalam bab-bab, tapi terpisah antara yang satu dengan yang lainnya ${ }^{11}$.

\section{Mekanisme Penetapan Harga dalam Perekonomian Islam Menurut Ibnu Khaldun}

\section{Mekanisme Pasar}

Ibnu Khaldun, membagi barang-barang menjadi dua katagori, yaitu barang pokok dan barang mewah. Menurutnya jika suatu kota berkembang dan jumlah penduduknya semakin banyak, maka harga barang-barang pokok akan semakin menurun sementara harga barang mewah akan naik. Hal ini disebabkan oleh meningkatnya penawaran barang pangan dan barang pokok lainnya sebab barang ini sangat penting dan dibutuhkan oleh setiap orang, sehingga pengadaannya akan diprioritaskan. Sementara itu, harga barang mewah akan naik sejalan dengan meningkatnya gaya hidup yang mengakibatkan peningkatan permintaan barang mewah ini.

\footnotetext{
${ }^{11}$ Ibnu Khaldun, Muqaddimah, hal 1085-1086
} 
Di sini, Ibnu Khaldun sebenarnya menjelaskan pengaruh permintaan dan penawaran terhadap tingkat harga. Secara lebih rinci ia menjelaskan pengaruh persaingan antara para konsumen dan meningkatnya biaya-biaya akibat perpajakan dan pungutan-pungutan lain terhadap tingkat harga.

Pengaruh tinggi rendahnya tingkat keuntungan terhadap perilaku pasar, khususnya produsen, juga mendapat perhatian dari Ibnu Khaldun. Menurutnya tingkat keuntungan yang wajar akan mendorong tumbuhnya perdagangan, sementara tingkat keuntungan yang terlalu rendah akan membuat lesu perdagangan. Para pedagang dan produsen lainnya akan kehilangan motivasi bertransaksi. Sebaliknya jika tingkat keuntungan terlalu tinggi perdagangan juga akan melemah sebab akan menurunkan tingkat permintaan konsumen. Ibnu Khladun sangat menghargai harga yang terjadi dalam pasar bebas, namun ia tidak mengajukan saran-saran kebijakan pemerintah untuk mengelola harga. Ia lebih banyak memfokuskan kepada faktor-faktor yang mempengaruhi harga.

Beberapa faktor menurut Ibnu Khaldun yang dijadikan indikator dalam kegiatan suatu perekonomian di suatu pasar adalah : a) Kekuatan Permintaan dan Penawaran; b) Tinggi rendahnya suatu pajak (bea cukai); c) Biaya Produksi; d Perilaku penimbuan (Monopoli)

Secara umum dapat disampaikan bahwa kemunculan pesan moral Islam dan pencerahan teori pasar, dapat dikaitkan sebagai bagian dari reaksi penolakan atas sistem sosialisme dan sekularisme. Meskipun tidak secara keseluruhan dari kedua sistem itu bertentangan dengan Islam. Namun Islam hendak menempatkan segala sesuatu sesuai pada porsinya, tidak ada yang dirugikan, dan dapat mencerminkan sebagai bagian dari the holistic live kehidupan duniawi dan ukhrowi manusia. Oleh sebab itu, sangat utama bagi umat Islam untuk secara kumulatif mencurahkan semua dukungannya kepada ide keberdayaan, kemajuan dan kecerahan peradaban bisnis dan perdagangan. Islam secara ketat memacu umatnya untuk bergiat dalam aktivitas keuangan dan usaha-usaha yang dapat meningkatkan kesejahteraan social.

Berdagang adalah aktivitas yang paling umum dilakukan di pasar. Untuk itu teks-teks Al Qur'an selain memberikan stimulasi imperative untuk berdagang, di lain pihak juga mencerahkan aktivitas tersebut dengan sejumlah rambu atau aturan main yang bisa diterapkan di pasar dalam upaya menegakkan kepentingan semua pihak, baik individu maupun kelompok 
Konsep Islam menegaskan bahwa pasar harus berdiri di atas prinsip persaingan bebas (perfect competition). Namun demikian bukan berarti kebebasan tersebut berlaku mutlak, akan tetapi kebebasan yang dibungkus oleh frame syari' ah. Dalam Islam, Transaksi terjadi secara sukarela (antaradim minkum/mutual goodwill, Sebagaimana disebutkn dalam Qur'an surat An Nisa' ayat 29. Didukung pula oleh hadits riwayat Abu dawud, Turmudzi, dan Ibnu Majjah dan as Syaukani se bagai berikut:

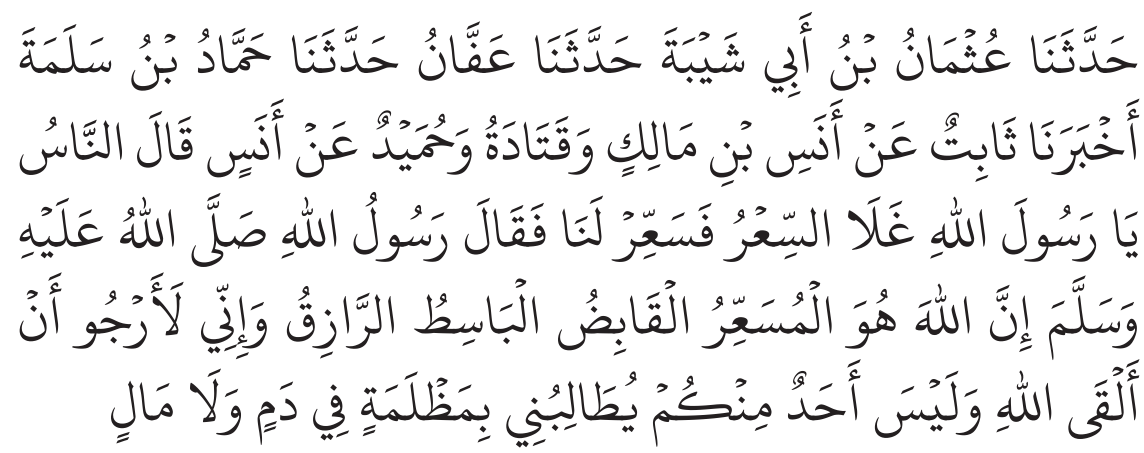

"Orang-orang berkata: "Wahai Rasulullah, harga mulai mahal. Patoklah harga untuk kami!” Rasulullah SAW bersabda, "Sesungguhnya Allahlah yang mematok harga, yang menyempitkan dan yang melapangkan rizki, dan aku sungguh berharap untuk bertemu Allah dalam kondisi tidak seorangpun dari kalian yang menuntut kepadaku dengan suatu kezhaliman-pun dalam darah dan harta". (HR Abu Dawud, atTirmidzi, Ibnu Majah, dan asy-Syaukani).

Selanjutnya pasar yang adil akan melahirkan harga yang wajar dan juga tingkat laba yang tidak berlebihan, sehingga tidak termasuk riba yang diharamkan oleh Allah SWT. sebagaimana ayat berikut;

Artinya: Orang-orang yang makan (mengambil) riba tidak dapat berdiri melainkan seperti berdirinya orang yang kemasukan syaitan lantaran (tekanan) penyakit gila. keadaan mereka yang demikian itu, adalah disebabkan mereka Berkata (berpendapat), Sesungguhnya jual beli itu sama dengan riba, padahal Allah Telah menghalalkan jual beli dan mengharamkan riba. orang-orang yang Telah sampai kepadanya larangan dari Tuhannya, lalu terus berhenti (dari mengambil riba), Maka baginya apa yang Telah diambilnya dahulu (sebelum datang larangan); dan urusannya (terserah) kepada Allah. orang yang kembali (mengambil riba), Maka orang itu adalah penghuni-penghuni neraka; mereka kekal di dalamnya. (QS Al Baqarah: 275) 
Dalam pada itu, transaksi yang dilakukan secara benar dan tidak masuk dalam riba dalam mencari keutamaan Allah bahkan mendapat dukungan yang kuat dalam agama. "Dan carilah apa yang telah dianugerahkan Allah kepadamu (kebahagiaan) negeri akhirat, dan janganlah kamu melupakan bagianmu dari (kenikmatan) dunia dan berbuat baiklah ... (QS. Al Qoshos: 77)

\section{Penetapan Harga}

Penetapan harga adalah apabila penguasa atau wakilnya atau siapa saja yang memimpin umat Islam memerintahkan pelaku pasar untuk tidak menjual barangnya kecuali dengan harga tertentu, maka dilarang untuk menambah atau menguranginya untuk kemaslahatan. ${ }^{12}$

Rasulullah Saw, Bersabda:

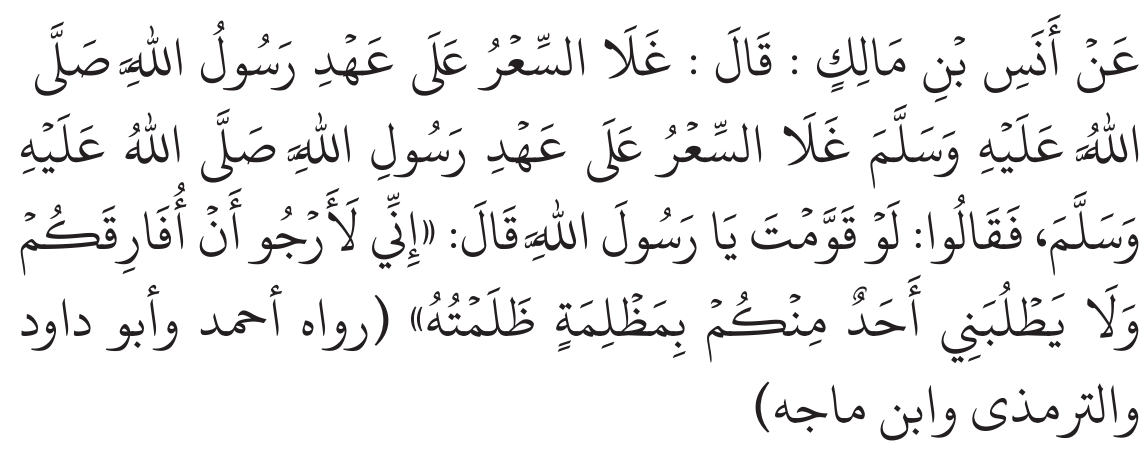

Dari Anas bin Malik ra,ia berkata: "Harga pernah melambung mahal di masa Rasulullah saw, maka manusia berkata: "Wahai Rasulullah, harga melambung mahal, maka buatlah patokan harga untuk kami”. Jawab beliau: "Sesungguhnya Allah Yang Maha Mengendaki harga menjadi mahal, Yang Menahan, Yang Melapangkan rejeki dan Yang Maha Pemberi rejeki. Sesungguhnya aku berharap menghadap Tuhanku, dalam keadaan tidak ada seorang pun dari kalian yang menuntutku terzalimi di dalam darah dan harta". (HR. Ahmad, Abu Dawud, At-Tirmidzi dan Ibnu Majah).

Dalam karyanya yang fundamental, Ibnu Khaldun juga mendeskripsikan pengaruh kenaikan dan penurunan penawaran terhadap tingkat harga. Ia menyatakan, "Ketika barang-barang yang tersedia sedikit, maka hargaharga akan naik. Namun, bila jarak antar kota dekat dan aman untuk

${ }^{12}$ Jabirah bin Ahmad Al Hatitsi, Fikih Ekonomi Umar bin Al Khathab,2010, Terj. Al Figh Al Iqtishadi Li Amiril Mukminin Umar Ibnu Al Khaththab, (Jakarta Pustaka al Kautsar), hal 613. 
melakukan perjalanan, maka akan banyak barang yang diimpor sehingga ketersediaan barang-barang akan melimpah dan harga-harga akan turun."13

Dari pendapat Ibnu Khaldun di atas, dapat dipersentasikan dalam bentuk kurva seperti di bawah ini,

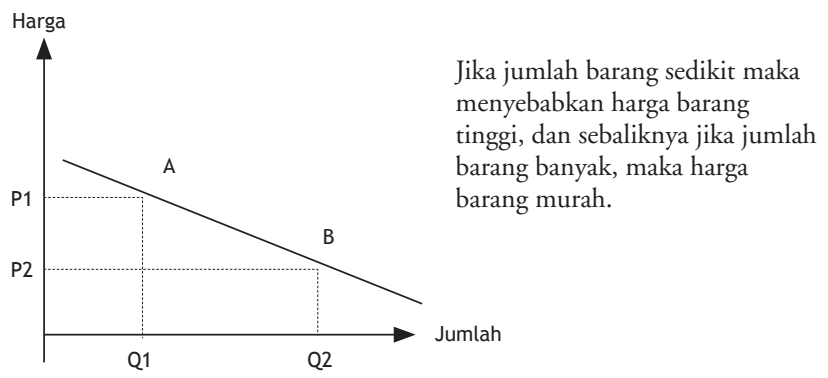

Formulasi ini menunjukkan bahwa pengaruh harga terhadap jumlah permintaan suatu komoditi adalah negatif, apabila $\mathrm{P} \uparrow$ maka $\mathrm{Q} \downarrow$ begitu sebaliknya apabila $\mathrm{P} \downarrow$ maka $\mathrm{Q} \uparrow$. Dari formulasi ini kita dapat menyimpulkan bahwa hukum permintaan menyatakan bila harga komoditi naik maka akan direspon oleh penurunan jumlah komoditi yang dibeli. Begitu jugaapabila harga komoditi turun maka akan direspon oleh konsumen dengan meningkatkan jumlah komoditi yang dibeli ${ }^{14}$.

Pendapat ini sejalan dengan apa yang dikemukakan oleh Ibnu Taimiyah, harga ditentukan oleh kekuatan permintaan dan penawaran. Ia mengemukakan,

Naik dan turunnya harga tidak selalu diakibatkan oleh kezaliman orangorang tertentu. Terkadang, hal tersebut disbabkan oleh kekurangan produksi atau penurunan impor barang-barang yang diminta. oleh karena itu, apabila permintaan naik dan penawaran turun, harga-harga naik di sisi lain, apabila persediaan barang meningkat dan permintaan terhadapnya menurun, harga pun menurun. Kelangkaan dan kelimpahan ini bukan disebabkan oleh tindakan orang-orang tertentu. Ia bias jadi disiapkan oleh orang-orang tertent. Ia bias jadi disebabkan oleh sesuatu yang tidak mengandung kezalima, atau terkadang ia juga, bias disebabkan oleh kezaliman. Hal ini adalah kemahakuasaan Allah yang telah menciptakan keinginan di hati manusi. ${ }^{15}$

\footnotetext{
${ }^{13}$ Adiwarman Karim, Ekonomi Mikro Islam, 2008 (Jakarta: RajaGrafindo Persada), hal 151.

${ }^{14}$ Adiwarman Karim, Sejarah Pemikiran Ekonomi Islam, 2010, (Jakarta RajaGrafindo Persada), hal 250.

${ }^{15}$ A. A. Islahi, Konsep Ekonomi Ibnu Taimiyah, Edisi Indonesia Penerj. Anshari Thayib, Bina Ilmu, 1997, hal 106.
} 
Teori Harga Ibnu Khaldun dalam kitab Muqaddimah-nya menulis satu bab yang secara khusus membahas mengenai mekanisme harga, bab tersebut berjudul 'harga-harga di kota'. Dalam bab tersebut menurut Ibnu Khaldun, bila suatu kota berkembang dan populasinya pun bertambah banyak maka rakyatnya akan semakin makmur, kemudian hal tersebut akan menyebabkan terjadiny $\mathrm{a}^{16}$ Telaah Kritis Pemikiran Ekonomi Islam Terhadap Mekanisme Pasar Dalam Konteks Ekonomi Islam Kekinian' kenaikan permintaan (demand) terhadap barang-barang, dan akibatnya harga menjadi naik. Franz Rosenthal yang menerjemahkan buku Muqaddimah karya Ibnu Khaldun menjadi The Muqaddimah: Artinya: Sesungguhnya apabila sebuah kota telah makmur dan berkembang serta penuh dengan kemewahan, maka di situ akan timbul permintaan (demand) yang besar terhadap barang-barang. Tiap orang membeli barang-barang mewah itu menurut kesanggupannya. Maka barangbarang menjadi kurang. Jumlah pembeli meningkat, sementara persediaan menjadi sedikit. Sedangkan orang kaya berani membayar dengan harga tinggi untuk barang itu, sebab kebutuhan mereka makin besar. Hal ini akan menyebabkan meningkatnya harga sebagaimana anda lihat. Seperti telah ditulis dalam kalimat diatas menurut Ibnu Khaldun dalam menentukan harga di pasar atas sebuah produksi, faktor yang sangat berpengaruh adalah permintaan dan penawaran.

Menurutnya apabila sebuah kota berkembang dengan pesat, mengalami kemajuan dan penduduknya padat, maka persedian bahan makanan pokok melimpah. Hal ini dapat diartikan bahwa penawaran yang meningkat mengakibatkan harga bahan/barang pokok tersebut murah. Ketika sebuah kota yang sangat maju dan memiliki banyak penduduk, harga bahan makanan dan barang-barang yang diperlukan menjadi rendah/murah... Ibnu Khaldun menekankan bahwa kenaikan penawaran atau penurunan permintaan menyebabkan kenaikan harga, demikian pula sebaliknya kenaikan permintaan atau penurunan penawaran akan menyebabkan penurunan harga.27 Analisa supply and demand Ibnu Khaldun tersebut di dalam ilmu ekonomi modern, diteorikan sebagai terjadinya peningkatan disposable income (kelebihan pendapatan) dari penduduk kota. Naiknya hal tersebut dapat menyebabkan naiknya marginal propersity to consume (kecenderungan marginal untuk mengkonsumsi) dari setiap penduduk kota terhadap barang mewah. Hal ini menciptakan kebutuhan baru atau peningkatan permintaan terhadap barang-

${ }^{16} 23$ P3EI, Ekonomi Islam, (Jakarta : Rajawali Pers, 2012), 301-345 24 Ulfa Jamilatul Farida, 
barang mewah. Akibatnya harga barang-barang mewah akan meningkat dengan sendirinya. Adanya kecenderungan tersebut dikarenakan oleh terjadinya disposable income penduduk kota seiring dengan berkembangnya kota itu. ${ }^{17}$ Inilah teori supply and demand-nya Ibnu Khaldun. Menurutnya penawaran bahan pokok di kota besar jauh lebih besar dari pada penawaran bahan pokok di kota kecil/desa. Sehingga hal tersebut mengakibatkan harga bahan pokok di kota menjadi lebih murah dikarenakan tingginya penawaran akan barang tersebut, dan hal sebaliknya terjadi di kota kecil/desa sehingga harga barang menjadi lebih mahal. Ketahuilah bahwa sesungguhnya semua pasar menyediakan kebutuhan manusia, di antaranya kebutuhan (primer), yaitu makanan pokok seperti gandum dan segala jenis makanan pokok lainnya seperti sayur buncis, bawang merah, bawang putih dan sejenisnya. Ada pula kebutuhan yang bersifat (sekunder) dan (tertier) yang merupakan kebutuhan pelengkap seperti bumbu makanan, buah-buahan, pakaian, perabot rumah tangga, kendaraan, dan seluruh produk hasil industri.

Apabila sebuah kota berkembang maju dan penduduknya padat (banyak), maka murahlah harga barang kebutuhan (primer) seperti makanan pokok dan menjadi mahal hargaharga barang kebutuhan pelengkap, Apabila penduduk suatu daerah sedikit (seperti desa) dan lemah peradabannya, maka terhadi sebaliknya.(terjadi harga mahal). Analisa Ibnu Khaldun tentang harga tersebut yang dirumuskan menggunakan hukum supply and demand adalah merupakan suatu rumusan yang luar biasa di zamannya, karena hal tersebut terjadi jauh sebelum para ekonom konvensional seperti Adam Smith, David Ricardo dkk. merumuskan teori tersebut. Dari kalimat pertama Ibnu Khaldun di atas dijelaskan bahwa pasar adalah tempat yang menyediakan kebutuhan manusia, baik itu kebutuhan primer, sekunder maupun tertier. $30 \mathrm{Ibnu}$ Khaldun juga menjelaskan akibat dari adanya pungutan dan pajak terhadap meningkatnya biaya produksi barang. Bea masuk dan bea lainnya yang dikenakan pada (makanan) di pasar dan di gerbang kota atas nama penguasa, dan pemungut retribusi pajak keuntungan dari transaksi bisnis tersebut yang diperuntukkan bagi kepentingan mereka sendiri, masuk ke dalam harga bahan makanan. Harga di kota-kota, dengan demikian, lebih tinggi dari harga di padang gurun, karena bea masuk dan bea dan pungutan lainnya sedikit atau tidak ada di antara (Badui), sedangkan sebaliknya terjadi di kota-kota,

17 Agustianto, "Pemikiran Ekonomi Ibnu Khaldun," http://shariaeconomics.wordpress.com /2011/02/26/pemikiran-ekonomi-ibnu-khaldun/ (12 Desember 2013) 
terutama di kemudian (tahun) dari dinasti. Dari penjelasan di atas dijelaskan bahwa akibat dari adanya pungutan dan pajak atas bea masuk barang ke kota mengakibatkan harga barang di kota menjadi lebih mahal daripada di desa. Dari situlah dijelaskan oleh Ibnu Khaldun pengaruh pajak terhadap harga-harga. Harga damai begitu istilah menyebutkan, sangat dibutuhkan oleh pedagang dan konsumen. Karena bila harga turun terlalu drastis maka pedagang akan dirugikan dan mendorong mereka keluar dari pasar, sedangkan ketika harga naik keterlaluan maka konsumen yang akan mengalami kerugian dan kesusahan. Harga damai sangat dibtuhkan oleh kedua pihak, karena ia tidak saja memungkinkan pedagang memperoleh cukup keuntungan yang ditolerir pasar tetapi juga membantu menciptakan kegairahan pasar dengan meningkatnya penjualan untuk memperoleh keuntungan. Akan tetapi, terkadang harga yang rendah juga dibutuhkan, karena seperti kita tahu kaum miskin menjadi mayoritas dalam populasi sehingga hal itu dapat memberikan kelapangan bagi mereka. 33 Dengan demikian, tingkat harga yang stabil dengan biaya hidup yang relative rendah menjadi pilihan masyarakat dengan sudut pandang pertumbuhan dan keadilan.

Kenaikan penawaran atau penurunan permintaan menyebabkan kenaikan harga, demikian pula sebaliknya. Ia percaya bahwa akibat dari rendahnya harga pasar akan merugikan perajin dan pedagang, sehingga mereka keluar dari pasar, sedangkan akibat drai tingginya harga akan menyusahkan konsumen, terutama kaum miskin yang menjadi mayoritas dalam sebuah populasi. Karena iti Ibnu Khaldun berpendapat ahwa harga rendah untuk kebutuhan pokok harus diusahakan tanpa merugikan produsen.

Dengan kata lain, Ibnu Khaldun berpendapat bahwa tingkat harga yang stabil daan biaya hidup yang relatif rendah adalah pilihan yang terbaik dengan tetap mengusahakan pertumbuhan dan keadlan untuk meningkatkan kesejahteraan masyarakat.

Faktor yang mempengaruhi penawaran menurut Ibnu Khaldun adalah banyaknyaa permintaan tingkat keuntungan relatif (tingkat harga), tingkat usaha manusia (produktivitas), besarnya tenaga buruh termasuk ilmu pengetahuan dan ketrampilan yang dimiliki, keamanan dan ketenangan, serta kemampuan teknik dan perkembangan masyarakat secara keseluruhan. Sedangkan faktor yang mempengaruhi permintaan adalah pendapatan, jumlah penduduk, kebiasaan dan adat istiadat masyarakat, serta pembangunan dan kemakmuran masyarakat secara umum. 
Jika dikaitkan mekanisme harga yang terdapat di Indonesia secara umum, adalah sama dengan apa yang dikemukakan oleh pemikir ekonomi Islam, Ibnu Khaldun.Dimana naik turunnya harga ditentukan oleh permintaan dan penawaran. Ketika permintaan akan suatu barang akan meningkat, dan barang yang ditawarkan sedikit, maka harga akan naik, dan ketika penawaran akan suatu barang meningkat sedangkan permintaannya sedikit maka harga akan menjadi rendah. Naik turunnya harga barang pada kondisi ini disebut sebagai harga yang alami.

Kenaikan harga biasanya terjadi pada momen-momen tertentu. Momen lebaran misalnya, akan mengakibatkan harga sembako, atau makanan akan menjadi tinggi, melebihi harga biasanya, begitu pula dengan harga daging di pasaran. Selain makanan dan sembako harga pakaian juga ikut naik, karena momen lebaran adalah momen berpakaian baru.

Selain itu, kenaikan harga juga dipengaruhi oleh peningkatan jumlah penduduk, dimana ketika jumlah penduduknya meningkat maka permintaan suatu barang akan meningkat dan harga akan naik, berbeda dengan dengan suatu daerah yang memiliki jumlah penduduk yang lebih sedikit, kemudian permintaan akan suatu barang rendah, sehingga harganya pun ikut turun.

Selanjutnya, Ibnu Khaldun juga berpendapat bahwa, harga di kota lebih murah dibandingkan dengan harga di pedesaan atau pedalaman. Hal ini terjadi karena suplai barang di perkotaan tinggi sehingga harga menjadi rendah atau stabil. Sedangkan harga di pedesaan atau pedalaman menjadi lebih tinggi karena suplai barangnya sedikit, sehingga penduduknya berlomba-lomba untuk menyimpan makanan, baik untuk satu bulan dua bulan dan bahkan bisa mencapai tahunan.

Pendapat ini sangat tepat. Contohnya adalah harga semen di Jakarta dan beberapa daerah di luar pulau Jawa. Semen di Jakarta itu Rp 50-60 ribu/sak, ke Jayapura jadi Rp 80-100 ribu. Dari Jayapura ke Wamena itu bisa jadi Rp 1 juta $^{18}$. Sedangkan harga semen di pegunungan tengah papua adalah Rp 2 juta/sak ${ }^{19}$. Begitu pun juga dengan harga barang-barang yang lain mengalami perbedaan harga antara di kota dan di desa.

Adapun mekanisme harga pada era Masyarakat Ekonomi Asean (MEA

18 http://finance.detik.com/read/2015/05/12/182222/2913408/4/turunkan-harga-semendi-wamena-pemerintah-gunakan-pesawat-hercules, Searching: 16/8/2015

19 http://finance.detik.com/read/2015/07/22/104157/2972545/4/3/harga-semen-rp-2juta-sak-di-papua-ini-cara-kementerian-pupr-mengatasinya, Searching: 16/8/2015. 
2015) tentunya mengalami penurunan. Karena suplai barang lebih tinggi dari pada permintaan pasar. Hal ini disebabkan karena masing-masing Negara membawa hasil produksinya dengan harga yang lebih rendah dibandingkan dengan barang produksi lokal. Pada keadaan ini maka para pemain pasar atau produsen yang kalah bersaing dalam masalah harga, akan keluar dari pasar tersebut.

Ibnu Khaldun membagi jenis barang menjadi dua jenis yakni barang kebutuhan pokok dan barang pelengkap. Menurutnya bila suatu kota berkembang dan selanjutnya populasinya bertambah banyak (kota besar) maka perdagangan barang-barang kebutuhan pokok mendapatkan prioritas. Supplay bahan pokok penduduk kota besar jauh lebih besar dari pada supplay bahan pokok penduduk kota kecil. Menurut Ibnu Khaldun penduduk kota besar memiliki supplay bahan pokok yang melebihi kebutuhannya sehingga harga bahan pokok dilkota besar relatif lebih murah. Sementara itu supplay bahan pokok di kota kecil relatif kecil, karena itu orang-orang khawatir kehabisan makanan, sehingga harganya relatif mahal.

Naiknya disposable income dapat meningkatkan marginal propensity to consume tehadap barang-barang mewah dari setiap penduduk kota tersebut. Hal ini menciptakan permintaan baru atau peningkatan permintaan terhadap barang-barang mewah, akibatnya harga barang mewah akan meningkat pula.

Pada bagian lain dari bukunya, khaldun menjelaskan pengaruh naik dan turunnya penawaran terhadap harga, ia mengatakan:

"Ketika barang-barang yang tersedia sedikit, harga-harga akan naik.

Namun, bila jarak antar kota dekat dan aman untuk melakukan

perjalanan, akan banyak barang yang diimpor sehingga ketersediaan barang akan melimpah, dan harga-harga akan turun".

Menurut Adiwarman Karim, Ibnu Khaldun juga mengamati fenomena tinggi rendahnya harga di berbagai Negara, tanpa mengajukan konsep apa pun tentang kebijakan kontrol harga ${ }^{20}$.

Pendapat Ibnu Khaldun sesuai dengan apa yang dikemukakan oleh amirul mukminin, Umar bin Khaththab.Diantara petunjuk yang jelas adalah perkataan Umar, "Sesungguhnya kami tidak memaksamu atas harga tertentu." Ini artinya membiarkan penentuan harga pada fluktuasi antara

${ }^{20}$ Adiwarman Karim, Ekonomi Mikro Islam, hal 151 
persediaan dan permintaan barang. Ketika terjadi pergerakan harga, baik naik atau turun, adalah akibat dari fluktuasi persediaan dan permintaan barang dalam keadaan normal, maka penentuan harga dalam keadaan seperti ini tidak diperbolehkan ${ }^{21}$.

Ketika ada campur tangan dari para pedagang untuk mempengaruhi harga pasar dan menyimpangkannya dari keadaan normal, sebagaimana dalam keadaannya monopoli, maka Negara melakukan campur tangan untuk meluruskannya. Karena ketika pedagang melakukan monopoli atau menjual barang ke pasar, maka dengan perbuatannya tersebut dia telah mempengaruhi fluktuasi persediaan dan permintaan barang untuk kemaslahatan pribadi, maka campur tangan Negara dalam keadaan tersebut adalah untuk kemaslahatan semua orang, mengalahkan kemaslahatan individu atau beberapa orang saja ${ }^{22}$.

Begitupun juga dengan pendapat Imam Yahya bin Umar. Dia berpendapat bahwa at ta'sir (penetapan harga) tidak boleh dilakukan. Dia berhujah dengan hadis nabi.

Dari Anas bin Malik ra,ia berkata: "Harga pernah melambung mahal di masa Rasulullah saw, maka manusia berkata: "Wahai Rasulullah, harga melambung mahal, maka buatlah patokan harga untuk kami”. Jawab beliau: "Sesungguhnya Allah Yang Maha Mengendaki harga menjadi mahal, Yang Menahan, Yang Melapangkan rejeki dan Yang Maha Pemberi rejeki. Sesungguhnya aku berharap menghadap Tuhanku, dalam keadaan tidak ada seorang pun dari kalian yang menuntutku terzalimi di dalam darah dan harta".(HR. Ahmad, Abu Dawud, AtTirmidzi dan Ibnu Majah).

Lebih jauh Imam Yahya bin Umar menyatakan bahwa pemerintah tidak boleh melakukan intervensi pasar, kecuali dalam dua hal, yaitu para pedagang tidak memperdagangkan barang dagangan tertentunya yang sangat dibutuhkan masyarakat sehingga dapat menimbulkan kemudaratan serta merusak mekanisme pasar. Dalam hal ini pemerintah dapat mengeluarkan para pedagang tersebutdari pasar serta menggantikannya dengan para pedagang yang lain berdasarkan kemaslahatan dan kemanfaatan umum.

Para pedagang melakukan peraktek siyasah al igbraq atau banting harga (dumping)yang dapat menimbulkan persaingan yang tidak sehat

\footnotetext{
${ }^{21}$ Jabirah bin Ahmad Al Hatitsi, Fikih Ekonomi Umar bin Al Khathab, hal 617.

${ }^{22}$ Jabirah bin Ahmad Al Hatitsi, Fikih Ekonomi Umar bin Al Khathab, hal 617-618.
} 
serta dapat mengacaukan stabilitas harga. Dalam hal ini pemerintah berhak memerintahkan para pedagang tersebut untuk menaikan kembali harga sesuai dengan harga yang berlaku dari pasar ${ }^{23}$.

Begitu juga dengan pendapat Abu Yusuf. Ia menentang penguasa yang menetapkan harga. Argumennya didasarkan pada hadis Rasulullag saw.,

"Pada masa Rasulullah SAW; harga-harga melambung tinggi. Para sahabat mengadu kepada Rasulullah dan memintanya agar melakukan penetapan harga. Rasulullah SAW bersabda, tinggi rendahnya harga barang merupakan bagian dari ketentuan Allah, kita tidak bias mencampuri urusan dan ketetapanNya."

Penting diketahui, para pengusaha pada periode itu umumnya memecahkan kenaikan harga dengan menambah suplai bahan makanan dan mereka menghindari kontrol harga. Kecendrungan yang ada dalam pemikiran ekonomi Islam adalah membersihkan pasar dari praktek penimbunan, monopoli, dan praktek korup lainya dan kemudian membiarkan penentuan harga kepada kekuatan permintaan dan penawaran. Abu Yusuf tidak dikecualikan dalam hal kecendrungan ini. ${ }^{24}$

Syaukani berkata, mausia diberi kuasa atas harta mereka, sementara penetapan harga membatasi mereka. Pemimpin diperintahkan untuk memelihara maslahat kaum muslimin. Dan perhatiannya terhadap maslahat pembeli dengan menjadikan harga murahtidaklah lebih utama dari pada perhatiaanya terhadap maslahat dengan menjadikan harga mahal. Apabila kedua hal ini saling berhadapan, maka keduanya diberikan kesempatan berijtihad. Diwajibkan pemmilik barang untuk menjual dengan harga yang tidak diridhainya bertentangan dengan firman Allah QS. An-nisa [4]: 29.

Hai orang-orang yang beriman, janganlah kamu saling memakan harta sesamamu dengan jalan yang batil, kecuali dengan jalan perniagaan yang Berlaku dengan suka sama-suka di antara kamu. dan janganlah kamu membunuh dirimu, Sesungguhnya Allah adalah Maha Penyayang kepadamu.(QS. An-nisa [4]: 29)

Disamping itu, penetapan harga akan mengakibatkan kelangkaan barang. Hal itu mengakibatkan kenaikan harga dan hal ini akan membahayakan bagi orang-orang fakir karena mereka tidak mampu membelinya. Sementara orang-

\footnotetext{
${ }^{23}$ Euis Amalia, Sejarah Pemikiran Ekonomi Islam, hal 116-117.

${ }^{24}$ Adiwarman Karim, Sejarah Pemikiran Ekonomi Islam, hal 253.
} 
orang kaya, mereka masih mampu membelinya di pasar gelap dengan kecurangan yang besar. Masing-masing dari keduanya pun masuk pada kesempitan dan kesusahan. Tidak ada maslahat yang terwujud di antara keduanya ${ }^{25}$.

Pendapat ini juga sependapat dengan seorang ekonom konvensional, yaitu Adam Smith. Ia berpendapat bahwa,

"Apabila pemerintah tidak secara aktif terlibat dalam mempengaruhi kegiatan ekonomi maka perekonomian itu dengan sendirinya mengatur dan membuat penyesuaian di dalam berbagai aspek kegiatan eknomi. Pengaturan yang bebas dari campur tangan pemerintah tesebut akan mewujudkan kegiatan ekonomi yang efesien."

Menurut sadono Sukino, Adam Smith memang mengakui bahwa pemerintah mempunyai peranan yang cukup penting dalam kehidupan suatu Negara. Tetapi peranannya tersebut terbatas pada menyediakan dan mengembangkan infrastruktur dan menjalankan administrasi pemerintahan. Ekonomi yang dianut adalah ekonomi pasar bebas. Dalam sistem ekonomi ini kegiatan-kegiatan dalam perekonomian sepenuhnya diatur oleh mekanisme pasar yang invisible hand. Interaksi diantara penjual dan pembeli di pasar (pasar barang dan produksi) akan menentukan corak produksi nasional yang akan diwujudkan dan caranya produksi nasional tersebut akan dihasilkan. ${ }^{26}$

Menurut Ibnu Taimiyah tujuan regulasi harga adalah untuk menegakkan keadilan serta memenuhi kebutuhan dasar masyarakat. Ibnu Taimiyah membedakan dua jenis penetapan harga, yakni penetapan harga yang tidak adil dan cacat hukum serta penetapan harga yang adil dan sah menurut hukum. Penetapan harga yang tidak sah dan cacat hukum adalah penetapan harga yang dilakukan pada saat kenaikan harga-harga terjadi akibat persaingan pasar bebas, yakni kelangkaan supply atau kenaikan demand ${ }^{27}$.Sekalipun tidak pernah menggunakan "kompetisi" secara eksplisit, beberapa penjelasan Ibnu Taimiyah mengisyaratkan pandangannya yang jelas mengenai kondisi kompetisi sempurana (perfect competition), khusus ketika membahas tentang fungsi pasar. Sebagai contoh ia menyatakan, "memaksa masyarakat untuk menjual barangbarang dagangan tanpa ada dasar yang mewajibkannya atau melarang

\footnotetext{
25 Sabiq, Sayyid, Fikih Sunah, hal 204.

${ }^{26}$ Sadono Sukirno, Mikro ekonomi teori pengantar, hlm 394.

${ }^{27}$ Adiwarman Karim, Sejarah Pemikiran Ekonomi Islam, hal 367-368.
} 
mereka menjual barang-barang yang diperbolehkan merupakan suatu kezaliman yang diharamkan.”

Pernyataan tersebut mengindikasikan bahwa masyarakat memiliki kebebasan sepenuhnya untuk masuk atau keluar pasar. Ibnu Taimiyah mendukung peniadaan berbagai unsur monopolistik dari pasar dan, oleh karenanya, menentang segala bentuk kolusi yang terjadi di antara sekelompok pedagang dan pembeli atau pihak-pihak tertentu lainnya ${ }^{28}$.

Ketika dalam keadaan darurat, seperti terjadi bencana kelaparan, Ibnu Taimiyah merekomendasikan kepada pemerintah agar melakukan penetapan harga serta memaksa para pedagang untuk menjual barangbarng kebutuhan dasar, seperti bahan makanan. Ia menyatakan,

"Inilah saatnya penguasa untuk memaksa seseorang untuk menjual barang-barangnya pada harga yang adil ketika masyarakat sangat membutuhkannya. Misalnya, ketika memiliki kelebihan bahan makanan sementara masyarakat menderita kelaparan, pedagang akan dipaksa untuk menjual barangnya pada tingkat harga yang adil.”

Lebih lanjut, ia berpendapat bahwa memaksa seseorang untuk menjual barang dagangannya tanpa alasan yang cukup merupakan hal yang dilarang. Namun, jika alasannya cukup, tindakan tersebut dapat dibenarkan.

Dalam melakukan penetapan harga, harus dibedakan antara para pedagang lokal yang memiliki persediaan barang dengan para importir. Dalam hal ini, para importir tidak boleh dikenakan kebijakan tersebut. Namun, mereka dapat diminta untuk menjual barang dagangannya seperti halnya rekanan importir mereka. Penetapan harga akan menimbulkan dampak yang merugikan persediaan barang-barang impor mengingat penetapan harga tidak diperlukan terhadap barang-barang yang tersedia di tempat itu, karena akan merugikan para pembeli ${ }^{29}$.

Kalau penulis kaitkan dengan kebijakan harga kebutuhan pokok di Indonesia, maka penulis katakan bahwa kebijakan harga kebutuhan pokok, sesuai dengan konsep yang diajukan oleh Ibnu Khaldun, yaitu pemerintah tidak menentukan harga, akan tetapi ketika ada pedagang yang sengaja menimbun barang dagangannya yang dibutuhkan oleh masyarakat, maka pemerintah boleh melakukan intervensi pasar. Contohnya adalah ketika

\footnotetext{
${ }^{28}$ Adiwarman Karim, Sejarah Pemikiran Ekonomi Islam, hal 367-368.

${ }^{29}$ Adiwarman Karim, Sejarah Pemikiran Ekonomi Islam, hal 369.
} 
harga daging sapi Rp 130.000 per kilogram pada bulan agustus $2015^{30}$, kemudian pemerintah melakukan sidak ke dua Feedloter yaitu, PT TUM dan BPS, penyidik menemukan 21.933 ekor sapi. Sementara 5.498 ekor adalah sapi siap potong ${ }^{31}$, sehingga para feedloter dipaksa untuk memotong sapi yang sudah siap potong agar harga kembali normal

\section{Penutup}

Berdasarakan hasil analisis Pemikiran Ibnu Khaldun Tentang Mekanisme Pasar Dan Penetapan Harga Dalam Perekonomian Islam, dapat disimpulkan:

Menurut pendapat Ibnu Khaldun, mekanisme harga ditentukan oleh permintaan dan penawaran yang terjadi secara alamiah. Ketika terjadi kenaikan harga secara alami yang disebabkan oleh sedikitnya barang atau banyaknya permintaan, maka itu artinya Allah ingin memberikan rizeki-Nya ke pada para pedagang, dan ketika terjadi penurunan harga yang terjadi karena melimpahnya barang atau sedikitnya permintaan, maka Allah ingin memberikan rizeki-Nya kepada para pembeli atau konsumen. Dan dalam hal ini juga penulis sependapat dengan apa yang dikemukakan oleh Ibnu Khaldun. Bahwa turun-naiknya harga dalam mekanisme harga, diakibatkan oleh penawaran dan permintaan. Menurut pendapat Ibnu Khaldun, pemerintah atau penguasa atau wakilnya tidak diperkenankan menetapkan harga. karena akan merugikan salah satu pihak, dan menguntungkan pihak yang lain. Kenaikan harga juga pernah terjadi pada masa Rasulullah Saw. Ketika itu para sahabat mengadu kepada RasulullahSaw, kemudian Rasulullah Saw, menjawab, "tinggi rendahnya harga barang merupakan bagian dari ketentuan Allah, kita tidak ias mencampuri urusan dan ketetapanNya. 'Pendapat tentang pelarangan para penguasa dalam menetapkan harga,merupakan pendapat kebanyakan ulama atau jumhur ulama. Di antaranya adalah seperti, Imam Yahya, Abu Yusuf, Imam Syaukani. Bahkan Adam Smith juga sependapat sebagaiman adalam teoriinvesibale hand. Dan penulis setuju dengan apa yang dikemukakan oleh Ibnu Khaldun, karena para pelaku pasar, baik

\footnotetext{
${ }^{30}$ http://wartakota.tribunnews.com/2015/08/24/aneh-tiap-bulan-agustus-harga-daging-sapiselalu-melonjak?page $=2$, Searching: 25/8/2015.

31 http://finance.detik.com/read/2015/08/21/154007/2997920/4/polisi-ungkap-pengakuan2-pengusaha-soal-seruan-tak-potong-sapi, Searching:25/8/2015.
} 
penjual maupun pembeli,diberikan kebebasan dalam bertransaksi dan menentukan harga.

\section{Pustaka Acuan}

Pusat Pengkajian dan Pengembangan Ekonomi Islam (P3EI) UII Yogyakarta. Ekonomi Islam, (Jakarta: PT RajaGrafindo Persada, 2008.

Farida, Ulfa Jamilatul,"Telaah Kritis Pemikiran Ekonomi Islam Terhadap Mekanisme Pasar

Dalam Konteks Ekonomi Islam Kekinian' dalam La_Riba-Jurnal Ekonomi Islam, 2012,

(Sleman: Universitas Islam Indonesia)

P3EI, Ekonomi Islam, 2014, (Jakarta : Rajawali Pers)

Karim, Adiwarman, Ekonomi Mikro Islam, 2008 (Jakarta: RajaGrafindo Persada)

Karim,Adiwarman, Sejarah Pemikiran Ekonomi Islam, 2010 (Jakarta: RajaGrafindo Persada)

Usman, Husaini, dkk, Metodologi Penelitian Sosial, 2008, (Jakarta: Bumi Aksara).

Departemen Pendidikan Nasional, Kamus Besar Bahasa Indonesia, 2008, (Jakarta: Gramedia Pustaka Utama)

https://id.wikipedia.org/wiki/Harga: Searcing;29-06-2015

Rosyidi, Suherman, Pengantar Teori Ekonomi, 1999, (Jakarta: RajaGrafindo Persada).

Nasution, Mustafa Edwin dkk, Pengenalan Ekslusif Ekonomi Islam, 2007 (Jakarta: Kencana Prenada Media Grup)

Pindyck, Robert S. Mikro Ekonomi, 2005, (Jakarta: PT. Indeks)

https://ekonomiana.wordpress.com/tag/penetapan-harga/: Seacrhing: 266-2015 Munir,Misbahul, Ajaran-Ajaran Ekonomi Rasulullah Kajian Hadits Nabi Dalam Perspektif Ekonomi, 2007, (Malang: UIN-Malang Press)

Khaldun,Ibnu, Muqaddimah, Terj. Masturi Ilham, dkk, 2014 (Jakarta: Pustaka Al Kautsar)

www. Google, http://pemikiran-ibnu-taimiyyah-tentang-mekanisme-pasardalam-ekonomi-islam/ 